研究論文

\title{
企業の情報開示とステークホルダー概念 一会計学研究に扣けるステークホルダー研究の援用可能性一
}

\section{要旨}

従来, 会計学の研究領域において，投資家以外のステークホルダーが，企業の情報開示の情報利用者とし て明示的に取り上げられて考察されることは，あまりなかった。しかし，最近では，企業の経済的側面だけ でなく社会的側面や環境的側面に関する情報を企業が自発的に開示する動きが広がっていることを受けて， 投資家以外のステークホルダーに対する関心が，会計学の研究領域においても高まっている，そこで，本稿 では, 経営学の研究領域におけるステークホルダー研究を援用して，ステークホルダー概念とその類型化の アプローチについて検討することを試みている，そして，ステークホルダーの類型化が, 類型化された各グ ループの情報ニーズに応じて，企業の情報開示において開示される情報内容を改善することに資することを 指摘し，今後の課題として，ステークホルダー研究の研究成果を会計学の研究領域に積極的に援用すること の必要性を主張している.

キーワード : 企業の情報開示, ステークホルダー概念, コーポレート・コミュニケーション，GRI ガイドラ イン, アカウンタビリティ

\section{1.はじめに}

最近, 会計学の研究領域において, 投資家以外のス テークホルダーに対する関心が高まっている.しかし， 従来, 会計学の研究領域において, 投資家以外のステー クホルダーが情報利用者として明示的に取り上げられ て考察されることは，あまりなかった，そこで，本稿 では, 経営学の研究領域に扔けるステークホルダー研 究を援用して, ステークホルダー概念について考察す ることを試みている.

まず，会計学の研究領域において，情報利用者とし て想定する者の範囲が拡大しつつあることを指摘す る. そして，こうした傾向が，企業の情報開示をコー ポレート・コミュニケーションの一形態として捉える 視座を与えるとともに, 会計学の研究領域においてス テークホルダー概念に焦点を当てることの必要性を示 唆していることを指摘する. つぎに, 経営学の研究領
域におけるステークホルダー研究の展開を概観し，ス テークホルダー概念とその類型化のアプローチについ て検討する. 最後に, ステークホルダーの類型化が, 類型化された各グループの情報ニーズに応じて, 企業 の情報開示において開示される情報内容を改善するこ とに資することを指摘し，今後の課題としてステーク ホルダー研究の研究成果を会計学の研究領域に積極的 に援用することの必要性を指摘することとする。

\section{2. 会計学研究における情報利用者の範囲と ステークホルダー概念}

\section{1 会計学研究が想定する情報利用者の範囲の拡大} 従来, 会計学の研究領域においては, 企業の情報開 示において開示される情報の中でもとりわけ財務報告 ないし財務諸表に明示的もしくは暗示的に焦点が当て られてきた，また，第一義的な情報利用者として投資 家に焦点が当てられてきた. このため, 従来, 会計学 
の研究領域では，投資家以外の情報利用者に主たる関 心が向けられることはあまりなかった

最近では，会計学の研究領域において，主たる情報 利用者として想定する者を投資家に限定せずに考察を 試みることが行なわれつつある，なかでも，多様なス テークホルダーの観点に立脚した新たな企業報告モデ ルが提言されている注1)，そして，従来の財務報告か ら新たな企業報告の枠組みへの展開を示唆する各モデ ルの特徴のひとつとして，投資家と一致する部分を除 くその他の情報利用者の情報ニーズが重視されている ことが指摘されている ${ }^{22)}$. 新たな企業報告のモデルの ひとつに, GRI ガイドライン ${ }^{5)}$ がある.

このように, 最近, 会計学の研究領域において, 投 資家以外のステークホルダーに対する関心が高まって いる. しかし, 会計学の研究領域において, ステーク ホルダー概念の含意ないし定義について明示的に取り 上げて考察されることは, 稀である注2).

\section{2 会計学研究においてステークホルダー概念 に焦点を当てる必要性}

情報利用者として想定する者の範囲の拡大化傾向 は, 会計学研究において企業の情報開示をコーポレー ト・コミュニケーションの一形態として捉える視座を 与えている.コーポレート・コミュニケーションの捉 え方に対するアプローチにはいくつかのものがある が，それらのうち企業と社会との「関連性」を重視し てコーポレート・コミュニケーションを捉えるアプ ローチは, 多様なステークホルダー全体に向けた企業 の情報開示の可能性, すなわち財務報告, 環境報告, 社会報告の統合化の可能性を示唆している ${ }^{18)}$. 多様な ステークホルダー全体に向けた企業の情報開示の可能 性を検討する場合には，情報利用者としてのステーク ホルダーの範囲を特定ないし類型化するとともに, 企 業が重視するステークホルダーを識別することが必要 である.

最近では，「CSR 報告書」や「サスティナビリティ 報告書」等の名称を付した媒体（以下，CSRに関す る報告書とする)を利用して, 多様なステークホルダー に向けて，企業の経済的側面だけでなく社会的側面や 環境的側面に関する情報を企業が自発的に開示する動 きが広がっている，CSRに関する報告書は，多様な ステークホルダーを情報利用者として想定し, 彼らと のコミュニケーションを図ることに重点を置いたもの であり，多様なステークホルダー全体に向けた企業の
情報開示の具体例と見ることができる．しかし，CSR に関する報告書の情報利用者としては，単に株主（投 資家), 債権者, 顧客, 取引先, 従業員といったように, 多様なステークホルダーが想定されていることが指摘 されるにとどまり，CSR に関する報告書の情報利用 者として具体的にどのようなステークホルダーが重視 されているのか，その優先順位は未だ充分に明らかに されていない注3).

前述の GRI ガイドラインは, 国際的に広まりつつ ある企業の広範な責任に関する情報開示ガイドライン であると指摘される27).こうしたことから，GRI ガイ ドラインは，多様なステークホルダー全体に向けた企 業の情報開示を指向する有力なガイドラインであると 言えよう. GRIガイドラインは, 主要ステークホルダー の定義および選出の根拠を開示することを規定してい る5). したがって，ステークホルダー概念に焦点を当 てることは, 今後ますます重要となるであろう.ステー クホルダー概念に焦点を当てることの必要性は, 会計 学の研究領域においても指摘されている ${ }^{11)}$.

\section{3. ステークホルダー研究の展開}

\section{1 ステークホルダー概念の多様性}

ステークホルダー概念は, 経営学の研究領域におけ る Freeman ${ }^{4)}$ に端を発し, 経営学の研究領域で広く 伝播した概念である，ところが，ステークホルダー概 念の含意ないし定義は, 経営学の研究領域に限定して も，極めて広範な各領域で論者によってさまざまに本 質的に異なるように論じられており，未だステークホ ルダー概念の確立された含意ないし定義は存在してい ない7 $\left.{ }^{7} 11,13\right)$, 注4). 以下, ステークホルダー概念の定義 をいくつか示す.

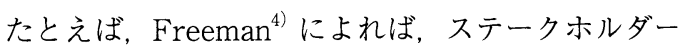
とは,「ある組織体の目標の達成に影響を及ぼすこと ができるか，もしくはそれによって影響を受ける個人

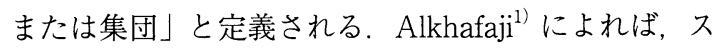
テークホルダーとは，「当該企業の存続に関して直接 的な利害を有する集団」と定義され，さらに「もし彼 らからの支持がなければ当該企業の存続可能性が危ぶ

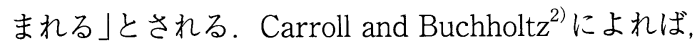
ステークホルダーとは，「組織が相互作用を持つある いは相互依存する個人または集団」と定義される. Lawrence, Weber and Post ${ }^{8)}$ によれば，ステークホル ダーとは,「ある組織体の意思決定，方針および活動 
に影響を及ぼすか，もしくはそれによって影響を受け る個人または集団」と定義される。

さらに,「ステークホルダー」という用語は, Freeman ${ }^{4)}$ 以降, 経営学の研究領域以外でも, 会計学の ほか, 企業倫理学, 経済学, 財務論, 政治学といったさま ざまな研究領域で用いられている11).そして, それぞれ の研究領域内に招いても,「ステークホルダー」という 用語が全く違うように定義されて用いられている7. こうした経緯から, ステークホルダー概念の含意ない し定義は，一義的に定まっていない.

\section{2 ステークホルダー概念の整理を試みる研究 アプローチの 2 類型}

経営学の研究領域におけるステークホルダーに関す る研究は, (1)ステークホルダー概念の整理を試みる研 究，(2)経営理論としてのステークホルダー理論の構築 を試みる研究，(3)経営実践の具体的指針としてのス テークホルダー・マネジメントの促進を試みる研究の 3 つに大別することができる26).このうち，(1)ステー クホルダー概念の整理を試みる研究は, 主に「企業と 社会」の理論において展開されている.

上述の(1)ステークホルダー概念の整理を試みる研究 はさらに，(1)特定種類の個人または集団がステークホ ルダーたり得るための属性を明らかにしようとするア プローチと，(2)ステークホルダーをそれに共通する何 らかの性質によって分類しようとするアプローチの 2 つに大別できる ${ }^{26)}$

(1)ステークホルダーたり得るための属性を明らかに しようとするアプローチには，限界がある，ステーク ホルダーたり得るための属性には，たとえば，関心 (interest), 持分 (share), 要求 (claim) がある2). こうしたステークホルダーたり得るための属性を有す る個人または集団は多数存在し, あらゆる個人, 集団, 地域, 組織, 機関, 社会, ひいては自然環境までもが 顕在的ないし潜在的にステークホルダーたり得ること になる ${ }^{9}$. かつ, ステークホルダーたり得るための属 性を有する個人または集団は，必ずしも1つの属性だ けを有しているとは限らず，複数の利害を有すること が少なくない，また，ステークホルダーたり得る個人 または集団は，企業環境や企業の置かれた時代背景に よって異なる。 そこで, 企業の情報開示において, 情 報利用者としてのステークホルダーの範囲を特定ない し類型化し， 企業が重視するステークホルダーを識別 する観点からは，(2)ステークホルダーをそれに共通す
る何らかの性質によって分類しようとするアプローチ が重要となる.

(2)ステークホルダーをそれに共通する何らかの性質 によって分類しようとするアプローチにはさまざまな ものがあるが，大別すると，「資源取引アプローチ」, 「明瞭性アプローチ」，「相互関係アプローチ」の $3 つ$ に類型化することができる注5)．以下では，これら 3 つのアプローチに属する各論者の見解をそれぞれ検討 する。

\section{4. ステークホルダー概念とその類型化のア プローチ}

\section{1 資源取引アプローチ}

資源取引アプローチは，ステークホルダーと企業と の資源的なつながりに着目したアプローチである ${ }^{21)}$. このアプローチには, 企業とステークホルダーとの関 係を形式的に捉えて，単に，ステークホルダーを第 1 次ステークホルダーと第 2 次ステークホルダーに分類 したり ${ }^{814)}$, ステークホルダーを外部ステークホルダー と内部ステークホルダーの 2 つに分類したりする ${ }^{22}$ 見 解が多い.

こうしたなかで, Wheeler and Sillanpää ${ }^{15)}$ は, 企 業に対して直接的ないし公的な関係を持っているかど うかによってステークホルダーを第 1 次ステークホル ダーと第 2 次ステークホルダーに区分し，さらに社会 的関係を持っているかどうかによってそれぞれを社会 的ステークホルダーと非社会的ステークホルダーに区 分している (表参照)。すなわち, ステークホルダー を，(1)第 1 次的社会的ステークホルダー (primary social stakeholders), (2)第 2 次的社会的ステークホル ダー (secondary social stakeholders), (3)第 1 次的非 社会的ステークホルダー (primary non-social stakeholders), (4)第 2 次的非社会的ステークホルダー (secondary non-social stakeholders), の 4 つのグルー プに分類している. (1)第 1 次的社会的ステークホル ダーは，当該組織とその成功に直接的な利害を有し， かつ当該組織とコミュニケーションを図ることが可能 な者である. (2)第 2 次的社会的ステークホルダーは, 当該組織の評判が疑われる場合にとりわけ強い影響力 を持つが，当該組織に対して直接的というよりはむし ろ代表参加的な利害を有し, かつ当該組織とコミュニ ケーションを図ることが可能な者である. (3)第 1 次的 非社会的ステークホルダーは, 当該組織とその成功に 
表 Wheeler and Sillanpää ${ }^{15)}$ によるステークホルダー概念の類型化

\begin{tabular}{|c|c|c|}
\hline & 第 1 次的ステークホルダー & 第 2 次的ステークホルダー \\
\hline $\begin{array}{c}\text { 社会的 } \\
\text { ステークホルダー }\end{array}$ & $\begin{array}{l}\text { 地域社会 } \\
\text { 供給業者と取引関係者 } \\
\text { 顧客 } \\
\text { 投資家 } \\
\text { 従業員と経営者 }\end{array}$ & $\begin{array}{l}\text { 政府と市民社会 } \\
\text { 社会的, 第三世界への関連団体等 } \\
\text { メディアや評論家 } \\
\text { 取引団体 } \\
\text { 競争業者 }\end{array}$ \\
\hline $\begin{array}{c}\text { 非社会的 } \\
\text { ステークホルダー }\end{array}$ & $\begin{array}{l}\text { 自然環境 } \\
\text { 人類以外の種 } \\
\text { 未来世代 }\end{array}$ & $\begin{array}{l}\text { 環境団体 } \\
\text { 動物愛護団体 }\end{array}$ \\
\hline
\end{tabular}

(出所) Wheeler and Sillanpää（参考文献15, p.5, Figure 1-1）をもとに, 水尾（参考文献 24, p.34, 図表 1) を参照して作成.

直接的な利害を有するが, 当該組織とコミュニケー ションを図ることが困難な者である。(4)第 2 次非社会 的ステークホルダーは, 当該組織に対して代表参加的 な利害を有するが，当該組織とコミュニケーションを 図ることが困難な者である、ただし，Wheeler and Sillanpää ${ }^{15)}$ は, これら 4 つのグループの相対的な重 要性については何も言及していない。

また, Post, Preston and Sachs ${ }^{10)}$ は, 企業の戦略的 環境を構成する次元として, (1)資源基盤（resource base), (2)産業構造 (industry structure), (3)社会· 政治的環境（social-political area）を示し, この3つ の枠組みを用いてステークホルダーを分類している (図一1参照)。ただし, Post, Preston and Sachs ${ }^{10)}$ は, この 3 つの枠組みに含まれるステークホルダーの相対 的な重要性については何も言及していない.ここで示
されたPost, Preston and Sachs ${ }^{10)}$ によるステークホ ルダーの類型化の特徵としては,「第 1 次ステークホ ルダー」の資源が企業に固有のものと業界に共通のも のとに分類されていることや，企業が存立する業界や 社会の制度構造が資源として捉えられるとともに, 行 政や一般社会がそのような資源の提供者として捉えら れていること, がある ${ }^{21)}$.

\section{2 明瞭性アプローチ}

明瞭性アプローチは, Mitchell, Agle and Wood ${ }^{9)}$ が 提唱したものであり，潜在的なステークホルダーの中 からその存在が相対的に明確なものを特定し, 経営者 が特定のステークホルダーとの関係構築を優先させる ベきことを明らかにしょうとするアプローチである21).

Mitchell, Agle and Wood ${ }^{9)}$ は, ステークホルダーを 分類する属性として，(1)当該企業に影響を与えるス

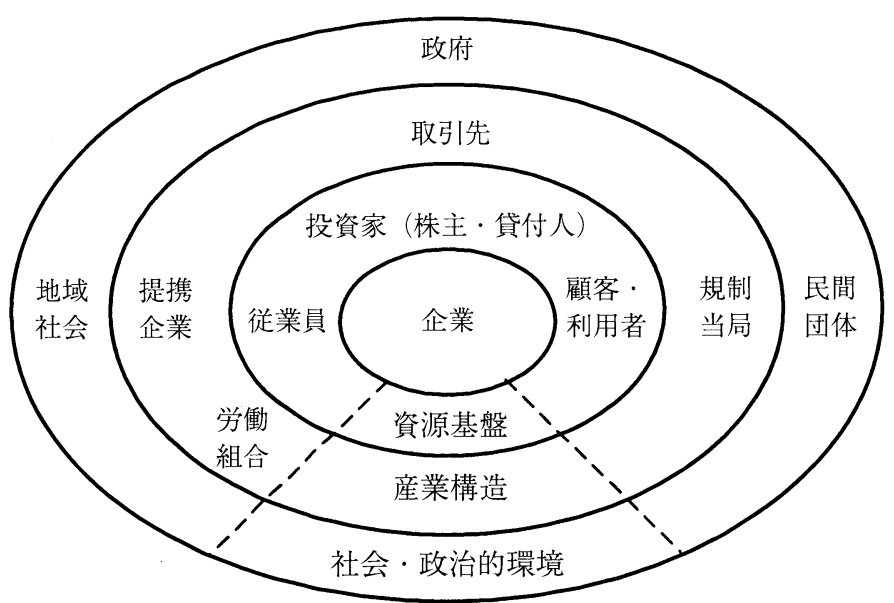

(出所) Post, Preston and Sachs (参考文献10, p.55, Figure 2.1)をもとに, 鈴木 (参 考文献21，p.241，図表12-1）を参照して作成.

図一 1 Post, Preston and Sachs ${ }^{10)}$ によるステークホルダー概念の類型化 
テークホルダーの権力 (power), (2)ステークホルダー と当該企業との関係の正当性 (legitimacy), (3)当該 企業に対するステークホルダーの要求の緊急度 (urgency)，を挙げて，これら 3 つ属性を用いてス テークホルダーを 7 つグループに分類し，また各グ ループを潜在的ステークホルダー，期待的ステークホ ルダー, 決定的ステークホルダーの3つに区分してい る（図ー2を参照）。これら 3 つ属性のいずれも有 さない者は, ステークホルダーとはならない. そして, これら 3 つ属性うち重複して複数の属性を有するグ ループほど, 経営者が関係構築を優先させるべきであ るとされる。

\section{3 相互関係アプローチ}

相互関係アプローチは, 企業とステークホルダーと の相互関係に着目したアプローチである ${ }^{21)}$.たとえば, Clarkson $^{3)}$, Savage et al. ${ }^{12)}$ が, 相互関係アプローチ に分類される。

Clarkson $^{3)}$ は, 当該組織の存続との関わり方を基準 として，ステークホルダーを，(1)中核的ステークホル ダー, (2)戦略的ステークホルダー, (3)環境的ステーク ホルダー,の 3 つのグループに分類している. (1)中核的 ステークホルダーとは, (2)戦略的ステークホルダーの 一部で，当該組織の存続に必要不可欠なステークホル ダーである. (2)戦略的ステークホルダーとは, 当該組織 にとって不可欠で, 特定の状況では当該組織が直面す
る脅威や機会となるステークホルダーである。（3)環境 的ステークホルダーとは，(1)中核的ステークホルダー でも(2)戦略的ステークホルダーでもない，当該組織を 取りまくその他のステークホルダーである.

また, Savage et al. ${ }^{12)}$ は, ステークホルダーを分類 する基準として，「協力者となる可能性」と「㓏威者 となる可能性」という 2 つの基準を挙げて，この $2 つ$ の基準を用いてステークホルダーを, (1協力的ステー クホルダー, (2)周縁ステークホルダー, (3)非協力的ス テークホルダー, (4)両義的ステークホルダー, の4つ のグループに分類している. (1)協力的ステークホル ダーとは, 脅威者となる可能性が低く, 協力者となる 可能性が高いステークホルダーである. (2)周縁ステー クホルダーは, 協力者となる可能性も脅威者となる可 能性も高くないステークホルダーである. (3)非協力的 ステークホルダーとは, 肙威者となる可能性が高く, 協力者となる可能性が低いステークホルダーである. (4)両義的ステークホルダーとは, 協力者となる可能性 も脅威者となる可能性もともに高いステークホルダー である．そして，それぞれのグループごとに異なる戦 略が取られるべきであるとされる（図ー 3 参照）.

相互関係アプローチは，企業の戦略的対応を検討す る上で有用であるとされ²1)，とりわけステークホル ダー・マネジメントないし CSR マネジメントの観点 から有用である。

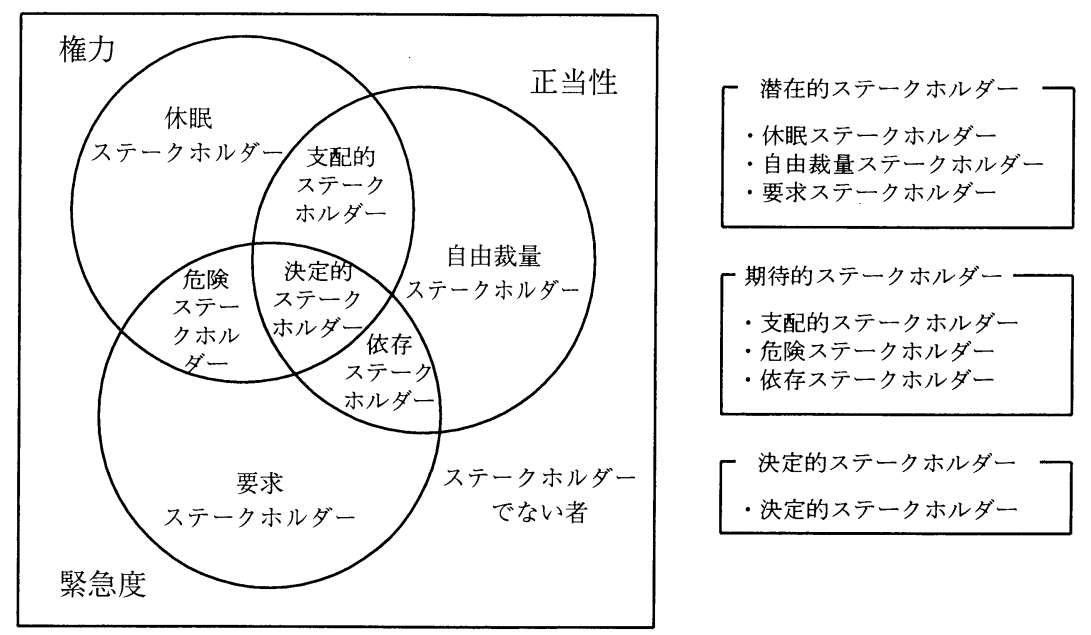

(出所) Mitchell, Agle and Wood（参考文献 9, p.874, Figure 2) をもとに, 鈴木（参考文献21, p.243, 図表12-2)，水村（参考文献25, p.234, 図 1) を参照して作成.

図ー2 Mitchell, Agle and Wood ${ }^{9}$ によるステークホルダー概念の類型化 


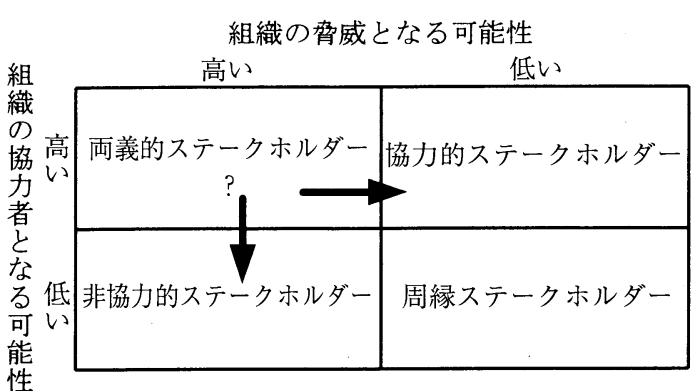

(出所) Savage et al. (参考文献12, p.65, Exhibit 2) をもとに, 鈴木（参考文献21，p.245，図表12-3）を参照して作成.

図ー 3 Savage et al. ${ }^{12)}$ によるステークホルダー概念の 類型化

\section{5. ステークホルダーの類型化と企業の情報 開示}

\section{1 ステークホルダーの類型化に伴う問題}

資源取引アプローチは，企業の情報開示において， 情報利用者としてのステークホルダーの範囲を特定な いし類型化する場合の一般的な方法である. しかし， 資源取引アプローチは, 多様なステークホルダーの相 対的な重要性を示すものではない，そこで, 企業が重 視するステークホルダーを識別する観点から, 明瞭性 アプローチや相互関係アプローチが必要となる。しか し，明瞭性アプローチや相互関係アプローチには，企 業の情報開示との関係で, 次のような問題点がある.

一般に, 企業の情報開示の役割のひとつとして, ア カウンタビリティの履行の手段となることが挙げられ る. 企業の経営責任が及ぶ範囲が，投資家（株主）を 超えて多様なステークホルダーにまで拡大するなら ば, 多様なステークホルダー全体に向けた企業の情報 開示は，彼らに対する拡張されたアカウンタビリティ の履行の手段となることが期待される ${ }^{17)}$.

しかし，明瞭性アプローチによれば，正当性を有す るステークホルダーでも, たとえば権力が弱く, 緊急 度も低い場合（すなわち, 自由裁量ステークホルダー に該当する場合）には，企業は彼らとの関係構築を優 先するべきではないことになる，したがって，企業が， 企業の情報開示の主たる情報利用者として彼らを自発 的かつ積極的に位置づけることはない，また，相互関 係アプローチによれば, 企業戦略上の重要性が低いと 判断されるステークホルダーに対して, 企業は自発的 かつ積極的に情報を開示するべきではない．まして，
企業にとって脅威となるステークホルダーに対して, 企業が自らにとって不利益となる情報を開示すること は, 当然想定されない.

明瞭性アプローチや相互関係アプローチの観点か ら，企業が重視するステークホルダーではないからと いって，企業の情報開示の情報利用者としてのステー クホルダーの範囲から特定のステークホルダーを除外 することは，企業の情報開示を多様なステークホル ダーに対する拡張されたアカウンタビリティの履行の 手段と捉えることとは相容れない.

そこで，類型化された各グループの情報ニーズに応 じて，企業の情報開示において開示される情報内容を 改善するためには, これら 3 つのアプローチを相互補 完的ないし複合的に用いることによって，より効果的 なステークホルダーの分析や位置づけを行なうことが 必要となる，以下では，ステークホルダー分析にかか わるプロセスを概説する注6).

\section{2 ステークホルダー分析のプロセス}

\subsection{1 潜在的なステークホルダーの認識}

企業の情報開示の利用者としてどのステークホル ダーを重視するのかは，企業によって異なり得る。そ こで，企業はまず，明瞭性アプローチに依拠して，自 社にとっての潜在的なステークホルダー（ステークホ ルダーを分類する 3 つの属性のいずれかを有するス テークホルダー）を認識する．潜在的なステークホル ダーは，企業の情報開示の利用者の候補となるステー クホルダーである．潜在的なステークホルダーを識別 するに当たっては，資源取引アプローチを補完的に用 いて, たとえば株主(投資家), 債権者, 顧客, 取引先, 従業員といったように，当該企業との資源的なつなが りに着目してステークホルダーを具体的に列挙する.

\section{2 .2 企業と潜在的なステークホルダーとの間の 利害関係の認識}

つぎに，潜在的なステークホルダーの情報ニーズを 識別する観点から，企業と潜在的なステークホルダー との間に生じる利害関係を認識する。潜在的なステー クホルダーが必要とする情報は，企業と潜在的なス テークホルダーとの間に生じる利害関係にかかわる情 報である注7)。こうした利害関係は，経済的利害，社 会的利害, 環境的利害の 3 つに大別することができる. これら $3 つ の$ 利害関係は，互いに重なり合って存在し ていることから，潜在的なステークホルダーは，企業 に対して複合的な利害関係を有している（図ー4を参 


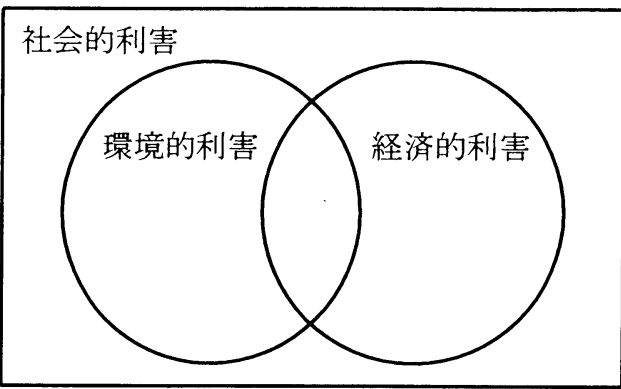

（出所）経済産業省（参考文献20, p.12, 図 II．3）をも とに作成。

図ー4 企業と潜在的なステークホルダーとの間 に生じる利害関係概念

照)，ここで，社会的利害は，企業と潜在的なステー クホルダーとの間において，名誉，地位ないし社会資 本の得失が生じ，信用，雇用㧍よび社会的地位に影響 を及ぼす関係をいう。経済的利害とは，企業と潜在的 なステークホルダーとの間において, 経済的得失が生 じる関係をいう，環境的利害とは，企業と潜在的なス テークホルダーとの間において，健康や生態系に影響 を及ぼす関係をいう 20)

\subsection{3 企業が重視するステークホルダーの特定}

続いて，明膫性アプローチや相互関係アプローチの 観点から考案した評価指標を用いて, 潜在的なステー クホルダーの中から企業が重視するステークホルダー をスコアリング方式で評価し，点数の高いステークホ ルダーほど，当該企業が重視するステークホルダーと して特定する．企業の情報開示においては，点数の高 いステークホルダーの情報ニーズに対応することを優 先することとし，企業の情報開示において開示される 情報内容を選定する。

明膫性アプローチの観点からは，ステークホルダー を分類する 3 つの属性，すなわち，(1)当該企業に影響 を与えるステークホルダーの権力, (2)ステークホル ダーと当該企業との関係の正当性，(3)当該企業に対す るステークホルダーの要求の緊急度，をそれぞれ示す 評価指標を考案する，たとえば，(1)当該企業に影響を 与えるステークホルダーの権力に関して，「当該企業 との密接度」や「当該企業との間に生じる利害関係の 大きさ」が評価指標として考えられる。 (2)ステークホ ルダーと当該企業との関係の正当性に関して，「社会 的視点からみたステークホルダーと当該企業との関係 の重要性」や「情報を公表する対象となる人数」が評
価指標として考えられる，(3)当該企業に対するステー クホルダーの要求の緊急度に関して,「ステークホル ダーに何らかの影響が生じるまでの時間」が評価指標 として考えられる。また，相互関係アプローチの観点 からは，当該企業にとって脅威や機会となる可能性を 示す評価指標を考案する。たとえば，「企業戦略との 関わりにおける重要性」や「情報を開示することによ る効果の大きさ」が評価指標として考えられる。

ただし,企業の情報開示において開示される情報は， 原則として広く一般に公表される情報であり，スコア リング評価において点数の高いステークホルダーだけ でなく，点数の低いステークホルダーも，企業の情報 開示において開示される情報を利用することができる ことは，妨げられない，そこで，企業の情報開示にお いて開示される情報内容を選定するに当たっては，企 業が重視するステークホルダーとして特定されなかっ たステークホルダーに対しても，情報が公表されるこ とになることに留意し，当該企業のすべての潜在的な ステークホルダーの存在を視野に入れる必要がある. 企業が重視するステークホルダーを識別する目的は, あくまで情報利用者の情報ニーズによりよく対応する べく，企業の情報開示において開示される情報内容を 絞り込むことにある。

\section{6.おわりに}

本稿では, 経営学の研究領域におけるステークホル ダー研究の展開を概観し，特にステークホルダーの類 型化を試みる研究について検討した。

本稿で検討したステークホルダーをそれに共通する 何らかの性質によって分類しようとするアプローチ は，企業の情報開示において，情報利用者としてのス テークホルダーの範囲を特定ないし類型化するととも に, 企業が重視するステークホルダーを識別する上で, 有益な示唆を与えている.

企業の情報開示をコーポレート・コミュニケーショ ンの一形態として捉える場合，企業の情報開示には， 多様なステークホルダーとの有効なコミュニケーショ ン手段となることがますます期待される。こうした観 点から，企業の情報開示において開示される情報内容 の改善に会計学の研究領域が貢献するには, 会計学の 研究領域においても，ステークホルダー概念に焦点を 当てることが必要である。しかし，本稿で検討したよ うに, 経営学の研究領域においても, ステークホルダー 
概念の確立された含意ないし定義は未だ存在しておら ず，コンセンサスを得ることのできる形で，ステーク ホルダー概念を定義することは, 現時点では極めて困 難である。，そもそも，ステークホルダーとなり得る個 人または集団は, 企業環境や企業の置かれた時代背景 によって異なる。しかし, 本稿で検討したステークホ ルダーをそれに共通する何らかの性質によって分類し ようとするアプローチに依拠して，ステークホルダー をいくつかのグループに類型化することは可能であ る. ステークホルダーの類型化を含め, 経営学の研究 領域におけるステークホルダー研究の研究成果を会計 学の研究領域に積極的に援用することが必要である。

\section{主要参考文献}

1) Alkhafaji, Abbass F. : A Stakeholder Approach to Corporate Governance: Managing in a Dynamic Environment, Quorum (1989)

2 ) Carroll, Archie B. and Ann K. Buchholtz: Business \& Society: Ethics and Stakeholder Management, 5th ed. South-Western, Thomson (2003)

3 ) Clarkson, Max B. E. (ed.) : Proceedings of the Second Toronto Conference on Stakeholder Theory, Toronto Centre for Corporate Social Performance and Ethics, University of Toronto (1994), cited by Carroll and Buchholtz $z^{2}$

4 ) Freeman, Edward R. : Strategic Management: A Stakeholder Approach, Pitman (1984)

5 ) Global Reporting Initiative (GRI) : Sustainability Reporting Guideline, Global Reporting Initiative (2002), 環境監査研究会訳：GRI サステナビリティリポーティン グガイドライン2002，GRI 日本フォーラム.(2002)

6 ) Institute of Chartered Accountants in England \& Wales (ICAEW) : New Reporting Models for Business. Institute of Chartered Accountants in England \& Wales (2003)

7 ) Kaler, John: Morality and Strategy in Stakeholder Identification, Journal of Business Ethics, 39 : 91-99 (2002)

8 ) Lawrence, Anne T., James Weber and James E. Post : Business and Society: Stakeholders, Ethics, Public Policy. 11th ed. McGraw-Hill Irwin (2005)

9 ) Mitchell, Ronald K., Bardley R. Agle and Donna J. Wood : Toward A Theory of Stakeholder Identification and Salience: Defining the Principle of Who and What Really Counts, Academy of Management Review, 22 (4) : 853-886 (1997)

10) Post, James E., Lee E. Preston and Sybille Saches: Redefining the Corporation: Stakeholder Management and Organizational Wealth, Stanford University Press (2002)

11) Robert, Robin W. and Lois Mahoney : Stakeholder Conceptions of the Corporation: Their Meanings and Influence in Accounting Research, Business Ethics Quarterly, 14 (3) : 399-431 (2004)

12) Savage, Grant T., Timothy W. Nix, Carlton J. Whitehead and John D. Blair: Strategies for Assessing and Managing Organizational Stakeholders, Academy of Management Executive, 5 (2) : 61-75 (1991)

13) Solomon, Jill and Aris Solomon: Corporate Governance and Accountability, John Wiley \& Sons (2004)

14) Steiner, George A. and John F. Steiner : Business Government, and Society: A Managerial Perspective, Text and Cases, 10th ed, McGraw-Hill (2003)

15) Wheeler, David and Maria Sillanpää : The Stakeholder Corporation: The Body Shop: Blueprint for Maximizing Stakeholder Value, Pitman (1997)

16）記虎優子：情報ニーズへの対応と企業の情報開示拡大化 に関する一考察，大阪成蹊短期大学研究紀要，(1)： 95-106 (2004)

17）記虎優子：企業の情報開示拡大化の理論的基礎一アカウ ンタビリティ概念の拡張可能性を中心に一，大阪成蹊短 期大学研究紀要, (2)：41-54 (2005)

18）記虎優子：会計学研究に扔けるコーポレート・コミュニ ケーション概念からの示唆一多様なステークホルダーを 指向した包括的企業情報開示の可能性一，産業経理，65 (1) : 100-107 (2005)

19）木下照葶：企業社会会計に関する一考察一現代企業に掠 ける利害関係者概念の発展と会計原則のあり方一, 會計, 115 (4) : 67-82 (1979)

20）経済産業省：ステークホルダー重視による環境レポーテ イングガイドライン2001（2001）(http://www.meti. go.jp/policy/eco_business/report01.html より入手)

21）鈴木賢志：企業のステークホルダー・リレーションズ, 谷本寛治編著, CSR 経営一企業の社会的責任とステーク ホルダー一, 中央経済社, 238-256(2004)

22）古庄修：CSR 情報開示と財務報告制度一英国の OFR 開 示規制を基軸として一，企業会計，56（9）：26-34（2004）

23）松尾聿正：環境会計と意思決定有用性, 山上達人 - 向山 敦夫 - 國部克彦編著, 環境会計の新しい展開, 白桃書房, 32-54 (2005)

24）水尾順一: 21 世紀に打ける経営倫理一コーポレート・ガ バナンスに扔るステークホルダーアプローチー, 日本 経営倫理学会誌, (8)：25-38 (2001)

25) 水村典弘：「利害関係者管理」の形成, 商学研究論集（明 治大学), (13)：229-247 (2000)

26）水村典弘：企業倫理の確立に向けた利害関係者管理の実 践一利害関係者を中核概念とする経営学的研究の現状と 課題一, 商学研究論集 (明治大学), (16)：83-99 (2002)

27）向山敦夫：CSR の数量化と測定方法, 企業会計, 56(9)： 35-41 (2004)

(本研究は, 平成16 18年度文部科学省科学研究費補助金若手 研究 (B) (課題番号16730248)による研究成果の一部である.)

\section{注}

1） $\mathrm{ICAEW}^{6)}$ は，最近の企業報告モデルの改善にかかわる提 言のレビューを行なっている.

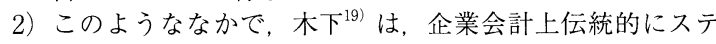
ークホルダーとして捉えられてきた株主・債権者よりも 広範な概念として，ステークホルダー概念を捉えること を試みている。

3）関西大学重点領域研究プロジェクト「企業に扔ける環境 マネジメントの大学への適用可能性に関する研究班」(代 表：中真道靖教授）のアンケート調查チーム（責任者： 松尾聿正教授）によって行なわれた, 環境報告書作成企 
業に対するアンケート調査においては，環境報告書の利 用者として企業が期待しているステークホルダーが，株 主・投資家，取引先，消費者および地域住民であること が示されている23).

4) Mitchell, Agle and Wood ${ }^{9)}$ は, ステークホルダー概念の 含意ないし定義に関する文献のレビューを行なっている.

5）ステークホルダーをそれに共通する何らかの性質によっ
て分類しようとするアプローチを「資源取引アプローチ」, 「明瞭性アプローチ」,「相互関係アプローチ」の3つに類 型化することは，鈴木 ${ }^{21)} に$ 依拠している.

6）ステークホルダー分析にかかわるプロセスは, 経済産業 省 ${ }^{20)}$ に部分的に依拠している.

7）ステークホルダーの情報ニーズについては, 記虎 ${ }^{16)}$ を参 照されたい.

\title{
The implications of stakeholder conceptions on corporate disclosure : An accounting perspective
}

Yuko KITORA

\begin{abstract}
Most accounting research has focused on investors as the principal users of corporate disclosure. Recently, stakeholders besides investors are also being focused on in accounting research as an increasing number of corporations voluntarily disclose not only their economic aspects but also social and environmental aspects. In this paper, approaches toward stakeholder conceptions and its categorization are discussed based on stakeholder research in management literature. This paper concludes that dividing stakeholders into categories helps corporations better meet each group's information needs, and as a result, stakeholder categorization can lead to improvement of the information content of corporate disclosure. This paper suggests that it is necessary to incorporate outcomes of stakeholder research into accounting research in a positive manner.

Key Words : Corporate Disclosure, Stakeholder Conceptions, Corporate Communication, GRI Guideline, Accountability
\end{abstract}

\section{他の学会や非営利団体の情報を掲載します}

以下の内容を下記学会事務局までE-mai1にてお送りください。

(1) 学会, 団体名

（2）掲載行事，情報

(3) 主催者, 担当者

（4）開催日時，締め切り日

(5) 申込先

（6）有料の場合，その金額

（7）URL（公開のURLがあればリンクをはります。詳細はそちらにアクセス してもらいます)

*本会会員へのサービスの一環として掲載いたしますので，採否および掲載内容， スタイルは小会へお任せください. 